\title{
EFEKTIFITAS EKSTRAK BELLADONA DALAM UPAYA MENANGANI FLOUR ALBUS PADA AKSEPTOR KB IUD
}

\section{THE EFFECTIVENESS OF EXTRACT BELLADONNA IN EFFORTS TO HANDLE THE FLOUR ALBUS IUD ACCEPTORS}

\author{
Melati Artika Wulansari ${ }^{1}$, Restiana Setyowati ${ }^{2}$ \\ Prodi DIII Kebidanan STIKES PKU Muhammadiyah Surakarta \\ email: jasminetol@ rocketmail.com
}

\begin{abstract}
Abstrak
Kontrasepsi IUD diminati oleh masyarakat yang tidak menginginkan efek hormon, tercatat pengguna kontrasepsi IUD sebesar (14\%) dan efek samping yang mungkin terjadi salah satunya adalah flour albus. Menyusun resume efektifitas ekstrak belladonna dalam upaya menangani flour albus pada akseptor KB IUD dan mengidentifikasi manfaat terapi ekstrak belladona untuk menangani flour albus pada akseptor KB IUD. Jenis penelitian ini menggunakan metode deskriptif dengan pendekatan study kasus. Subjek adalah pasien akseptor KB IUD dengan flour albus di BPM Eni Nogosari Boyolali. Tehnik pengumpulan data dengan cara wawancara, observasi, asuhan tujuh langkah varney dan catatan rekam medik serta menggunakan metode keabsahan data yaitu Standar Operasional Prosedur. Pasien yang menggunakan kontrasepsi IUD dengan flour albus di BPM Eni Nogosari Boyolali, penanganan yang diberikan adalah ekstrak belladonna diminum $2 x 1 /$ hari pagi dan sore dengan dosis $10 \mathrm{mg}$, setelah diberikan terapi ekstrak belladonna selama empat minggu keputihan teratasi. Tetapi dalam pemberian terapi klien dianjurkan vulva hygiene, menghindari makanan yg dapat menyebabkan keputihan serta diberikan terapi obat dexamethasone dan vit B complek. Maka dapat disimpulkan bahwa terapi ekstrak belladonna dikatakan efektif di dalam penanganan flour albus fisiologis yang berhubungan dengan antagonis kompetitif dan asetilkolin muscarinic.
\end{abstract}

Kata Kunci: Ekstrak belladona, flour albus, KB IUD.

\begin{abstract}
IUD contraception demands by people who don't want the effects of hormones, registered users of contraception IUD (14\%) and side effects that may occur one of which is flour albus. To compose resume extract belladonna effectiveness in responding flour albus to IUD acceptors and identify the benefits of therapy extracts belladonna in handling flour albus on IUD acceptors. This research used descriptive method with a case study approach. The subjects were the patients of IUD acceptors with flour albus. The technique of collecting data interview, observation, care seven steps varney and medical record and using methods the validity of data that Standard Operating Procedure. Patients who use the IUD with flour albus in BPM Eni Nogosari Boyolali, treatment is given is taken belladonna extract $2 x 1 /$ day morning and evening with a dose of $10 \mathrm{mg}$ whites. once given belladonna extract therapy for four weeks whitish resolve. But in the delivery of client care encouraged to vulva hygiene, eating diet that is not allowe and betel leaves are boiled, given the drug therapy of dexamethasone and vitamin B complek. It can be concluded that the extract belladonna is effective to therapy flour albus relating to antagonist competitive and acetylcholine muscarinic.
\end{abstract}

Keywords: Extractbelladonna, flour albus, IUD. 


\section{PENDAHULUAN}

Tujuan global pembangunan Millenium Development Goals (MDG's) adalah diharapkan pada 2015 angka kematian bayi turun menjadi 102 per 100.000 kelahiran hidup. Pencapaian tahun 2015 tersebut merupakan target komitmen global MDG's. Adapun salah satu kunci untuk mencapai tujuan pembangunan global MDG's adalah suksesnya program Keluarga Berencana (KB). Karena program KB dinilai dapat memberikan kontribusi terhadap delapan tujuan MDG's yang telah ditetapkan (Depkes RI, 2010).

Program KB masuk dalam salah satu dari delapan tujuan MDG's yaitu tujuan ke-5 yaitu meningkatkan kesehatan ibu yang terletak pada target $5 \mathrm{~b}$ yang berisi : tercapainya akses universal terhadap layanan Kesehatan Reproduksi (KemenKes RI, 2013).

Survei Demografi dan Kesehatan Indonesia tahun 2012 menyebutkan pola pemakaian kontrasepsi di Indonesia yaitu pil sebesar $41,2 \%$, suntik sebesar 43,33\%, MOW sebesar 3,7\%, kondom sebesar $4,7 \%$, implant sebesar 4,9\%, IUD sebesar $7,7 \%$, pantang berkala sebesar $1,5 \%$, senggama terputus sebesar 2,2\% dan metode lainnya sebesar $0,4 \%$ (Saifuddin, 2012).

Peserta KB di wilayah Jawa Tengah tahun 2012 sebesar 6.150.153 akseptor $(98,61 \%)$, kontrasepsi IUD diminati oleh masyarakat yang tidak menginginkan efek hormon, tercatat pengguna kontrasepsi IUD sebanyak 861.021 akseptor (14\%), MOW sebanyak 307.507 akseptor (5\%), kondom sebanyak 92.252 akseptor (1,5\%), pil sebanyak 1.292 .147 akseptor (21,01\%), suntik sebanyak 2.964 .373 akseptor $(48,2 \%)$, dan implant sebanyak 522.763 akseptor $(8,5 \%)$ (Saifuddin, 2012).

Pemerintah melalui lembaga Badan Koordinasi Keluarga Berencana Nasional (BKKBN) tengah menjalankan program Metode Kontrasepsi Jangka Panjang (MKJP) meliputi IUD, Implant, MOW, dan MOP sebesar 16,34\% dan yang tidak menggunakan MKJP seperti suntik, pil, kondom, pantang berkala, dan senggama terputus sebesar $63,86 \%$. IUD merupakan salah satu alat kontrasepsi modern yang telah dirancang sedemikian rupa (baik bentuk, ukuran, bahan, dan masa aktif fungsi kontrasepsinya), diletakkan dalam kavum uteri sebagai usaha kontrasepsi, menghalangi fertilisasi, dan menyulitkan telur berimplantasi dalam uterus (BKKBN, 2012).

Keuntungan IUD antara lain efektifitas tinggi, yaitu $0,6-0,8$ kehamilan per 100 perem- puan dalam 1 tahun pertama pemakaian, pada umumnya aman dan efektif, dapat digunakan hingga menopause. Adapun kerugian IUD yaitu tidak baik digunakan pada perempuan dengan IMS, penyakit radang panggul terjadi sesudah perempuan dengan IMS memakai IUD dapat memicu infertilitas, sedikit nyeri, tidak dapat melepas IUD oleh dirinya sendiri harus dengan petugas kesehatan yang terlatih, dan mungkin IUD keluar dari uterus tanpa diketahui (Nugroho, 2010).

Efek samping yang mungkin terjadi pada akseptor KB IUD yaitu perubahan siklus menstruasi sebanyak $4,26 \%$, peningkatan jumlah darah menstruasi $43,08 \%$, spotting $27,69 \%$, disminore $20,00 \%$, gangguan hubungan seksual $23,08 \%$, keputihan 44,62\%, perubahan tekanan darah $75,38 \%$. Kontrasepsi IUD bisa menyebabkan keputihan kerena keseimbangan ekosistem alat kelamin bergantung pada mikrobiota Lactobacillus yaitu mikroflora fakultatif dalam alat kelamin normal. Lactobacillus memproduksi asam laktat dari glukosa sehingga dapat mempertahankan PH alat kelamin menjadi asam $(<4,5)$. Alternative penanganannya yaitu konseling akseptor IUD tentang efek samping flour albusdan memberikan terapi ekstrak belladona (Leveno, 2012).

Berdasarkan data pengguna kontrasepsi IUD yang peneliti dapatkan dari hasil studi pendahuluan di BPM Eni, Amd.Keb Nogosari Boyolali jumlah akseptor KB pada tahun 2014 adalah 220 jiwa. Untuk kontrasepsi IUD sebanyak 120 akseptor $(54,54 \%)$, implant sebanyak 8 akseptor $(3,63 \%)$, suntik sebanyak 46 akseptor $(20,90 \%)$, pil sebanyak 27 akseptor $(12,27 \%)$, kondom sebanyak 19 akseptor $(8,63 \%)$. Pemakai kontrasepsi IUD dari 120 akseptor dengan efek samping yang sering muncul adalah perubahan siklus menstruasi terdapat 3 akseptor (1.36\%), peningkatan jumlah darah menstruasi terdapat 23 akseptor (10.45\%), spotting terdapat 18 akseptor (8.18\%), disminore terdapat 10 akseptor $(4,54 \%)$, flour albus terdapat 41 akseptor (18.63\%), perubahan tekanan darah terdapat 18 akseptor (8.18\%), gangguan hubungan seksual terdapat 7 akseptor (3.18\%). Dari data tersebut menunjukkan angka kejadian flour albus merupakan efek samping terbanyak dalam pemakaian akseptor KB IUD.Penanganan yang dilakukan untuk menangani flour albus di BPM Eni.Amd.Keb yaitu menggunakan terapi ekstrak belladonna yaitu antagonis kompetitif untuk reseptor asetilkolin 
muscarinic. Hal ini diklasifikasikan sebagai obat antikolinergik. Ini berguna untuk menyembuhkan keputihan dan menghilangkan bau yang tidak sedap. Selain itu juga diberikan terapi dexamethasone yaitu untuk anti inflamasi dan dan anti alergi, serta diberikan terapi B Complek yaitu untuk vitamin dan daya tahan tubuh.

Berdasarkan data-data tersebut penulis tertarik untuk mengambil studi kasus dengan judul "Efektifitas ekstrak belladona dalam upaya menangani flour albus pada akseptor KB IUD"

\section{METODE PENELITIAN}

Jenis observasi langsung pada pasien.Metode pengambilan data ini juga meliputi pemeriksaan inspeksi dan palpasi. Wawancara terstruktur adalah suatu metode yang digunakan peneliti untuk mendapat keterangan pendirian secara lisan dari responden dan bercakap-cakap berhadapan muka dengan orang tersebut. Dokumen yang digunakan dalam penelitian adalah pengkajian data hingga evaluasi yang ditulis bidan dalam rekam medis.

Tempat penelitian di BPM Eni Amd.Keb. Subjek penelitian pasien akseptor KB IUD dengan flour albus.

\section{HASIL DAN PEMBAHASAN Hasil Penelitian}

Berdasarkan penelitian yang dilakukan di BPM Eni Nogosari Boyolali diperoleh hasil sebagai berikut pasien dengan aseptor KB. Adapun keluhan utama pasien pada waktu masuk adalah pada tanggal 22 Februari 2015 telah mengeluarkan cairan berwarna putih bening yang berlebihan, tidak berbau dan tidak gatal sejak satu bulan yang lalu. Berdasarkan data kebidanan didapatkan lama siklus haid 28 hari dan selama haid tidak mengalami disminore, dan mengalami keputihan sebelum dan sesudah haid. Dalam riwayat kehamilan, persalinan, nifas yang lalu adalah pasien mempunyai satu anak berjenis kelamin laki-laki, tidak pernah keguguran, nifas yang lalu 40 hari normal dan anak sekarang dalam keadaan sehat. Data riwayat KB diperoleh pasien menggunakan KB kalender pada tahun 2010-2012 karena takut akan terjadinya kehamilan pasien berganti alat kontrasepsi yaitu KB IUD (CuT 380A) terhitung dari tahun 2012. Berdasarkan riwayat penyakit, pasien tidak mengalami riwayat penyakit GO dan sipilis.

Berdasarkan pemeriksaan fisik dilakukan pemeriksaan umum didapatkan hasil pemeriksaan yaitu keadaan umum baik, kesadaran composmentis, tekanan darah $120 / 70 \mathrm{mmHg}$, nadi $80 \mathrm{x} /$ menit, suhu $36,8^{\circ} \mathrm{C}$, pernapasan $24 \mathrm{x} /$ menit. Pengukuran fisik antara lain tinggi badan $155 \mathrm{~cm}$, berat badan $52 \mathrm{~kg}$, LILA $24,5 \mathrm{~cm}$, status present genetalia terdapat cairan yang berwarna puth bening, tidak berbau, genetalia tidak oedema, warna merah muda, dan pemeriksaan head to toe dalam batas normal. Dan dilakukan pemeriksaan inspekulo yaitu terdapat cairan berwarna putih bening, tidak berbau, tidak ada radang pada portio, benang IUD masih terlihat dan terpasang dengan baik.

Adapun hasil pengkajian didapat data subjektif dan data objektif maka ditegakkan diagnosa kebidanan pada pasien akseptor KB IUD (CuT 380A) dengan flour albus fisiologis, penanganan yang diberikan pada hari Minggu, 22 Februari 2015 pukul 17.10 WIB adalah memberitahu ibu efek samping IUD yaitu keputihan, perdarahan, nyeri, pindahnya IUD, dan keluarnya IUD, bahwa keputihan ini termasuk salah satu efek samping dari KB spiral (IUD), karena keseimbangan ekosistem alat kelamin bergantung pada mikrobiota lactobacillus yaitu mikroflora fakultatif dalam alat kelamin normal. Lactobacillus memproduksi asam laktat dari glukosa sehingga dapat mempertahankan $\mathrm{PH}$ alat kelamin menjadi asam (< 4,5). Memberitahu ibu tentang personal hygiene, yaitu mandi $2 x /$ hari, sikat gigi $2 x / h a r i$, ganti baju $2 x /$ hari, membersih

kan alat kelamin setiap sehabis BAK atau BAB dengan cara cebok dari arah muka kemaluan ke belakang anus, dan mengganti celana dalam tiap hari dan jika basah atau pada saat keputihan banyak, pakaian dalam yang bisa menyerap keringat dan berbahan katun, jangan menggunakan celana ketat (Hidayat, 2006).

Menurut Nugroho (2010), menggunakan pantyliner hendaknya dipilih yang tidak mengandung pengharum dan tidak digunakan selama lebih dari 4-6 jam.Memberitahu ibu makanan yang tidak diperbolehkan saat keputihan yaitu makanan yang mengandung ragi, buah-buahan yang dikeringkan seperti apel, melon, strowbery, dan see food. Sedangkan makanan yang mengurangi keputihan yaitu yogurt, sayur-sayuran, dan daun sirih yang direbus. Memberikan terapi obat yaitu ekstrak belladonna (10mg) jumlah 50 tablet diminum $2 \times 1 /$ hari yaitu pagi dan sore, dexamethasone $(0,5 \mathrm{mg})$ jumlah 12 tablet diminum $3 \times 1 /$ hari, B complek (300mg) jumlah 12 tablet diminum $3 \times 1 /$ hari. Serta memberikan support atau 
dukungan kepada ibu, jangan cemas dengan keadaannya dan lanjutkan KB spiralnya, dan memberitahu kunjungan ulang satu minggu lagi.

Berdasarkan pengkajian yang dilakukan pada kunjungan pertama yaitu tanggal 1 Maret 2015 diperoleh keadaan umum dan vital sign dalam batas normal tetapi keputihan yang keluar masih banyak. Penanganan yang dilakukan adalah melanjutkan minum terapi ekstrak belladonna yaitu diminum $2 \times 1 /$ hari, diberikan terapi dexamethasone dan B complek diminum 3x/hari, serta mengingatkan ibu lagi supaya menjaga personal hygieneterutama vulva hygiene, dan diet makanan yang tidak diperbolehkan saat keputihan.

Berdasarkan pengkajian yang dilakukan pada kunjungan kedua yaitu tanggal 7 Maret 2015 diperoleh keadaan umum, vital sign dalam batas normal dan keputihannya sudah berkurang, warna putih bening, tidak berbau.Penanganan yang dilakukan adalah melanjutkan terapi ekstrak belladona diminum $2 \times 1 /$ hari dan mengingatkan untuk menjaga personal hygiene terutama vulva hygiene, dan diet makanan yang tidak diperbolehkan saat keputihan.

Berdasarkan pengkajian yang dilakukan pada kunjungan ketiga yaitu tanggal 9 Maret 2015 diperoleh keadaan umum dan vital sign dalam batas normal dan keputihan yang keluar sudah sedikit tidak seperti kemarin.Penanganan yang dilakukan adalah melanjutkan terapi ekstrak belladona diminum $2 \times 1 /$ hari dan menganjurkan pasien untuk tetap menjaga personal hygiene terutama vulva hygiene, dan diet makanan yang tidak diperbolehkan saat keputihan.

Berdasarkan pengkajian yang dilakukan pada kunjungan keempat yaitu tanggal 28 Maret 2015 diperoleh keadaan umum, vital sign dalam batas normal dan sudah tidak mengeluarkan keputihan.Penanganan yang diberikan adalah menganjurkan ibu untuk tetap melakukan personal hygiene terutama vulva hygiene yaitu untuk mencegah terjadinya keputihan lagi dan memberitahu ibu untuk menghentikan minum obat ekstrak belladona karena keputihan ibu sudah berhenti, tetapi jika terjadi keputihan lagi bisa minum obat ekstrak belladona atau jika ada keluhan segera datang ketenaga kesehatan atau bidan.

\section{Pembahasan}

Kasus pada pasien KB IUD (CuT 380A) dengan flour albus di BPM Eni Nogosari Boyolali. Penyebab dari keputihan yaitu penggunaan alat kontrasepsi berupa KB IUD. Sesuai dengan teori Martin (2012), IUD bisa menyebabkan flour albus karena keseimbangan ekosistem alat kelamin bergantung pada mikrobiota lactobacillus yaitu mikroflora fakultatif dalam alat kelamin normal. Lactobacillus memproduksi asam laktat dari glukosa sehingga dapat mempertahankan $\mathrm{PH}$ alat kelamin menjadi asam $(<4,5)$. PH genetalia normalnya $(3,8-4,5)$. Untuk mengatasi masalah tersebut yaitu memberikan terapi ekstrak belladona.

Menurut teori dari Martin (2012), menyatakan bahwa jenis terapi ekstrak belladona untuk mengatasi flour albus sangat tergantung pada keadaan pasien dan kemampuan untuk minum terapi tersebut. Oleh sebab itu, terapi ekstrak belladonna hendaknya diminum secara teratur yaitu $2 \times 1 /$ hari pagi dan sore. Setelah pemberian terapi ekstrak belladona selama empat minggu dengan dosis $10 \mathrm{mg}$ keputihan teratasi. Tetapi dalam pemberian asuhan pada klien disini tidak hanya diberikan terapi ekstrak belladona tetapi dianjurkan untuk melakukan personal hygiene terutama untuk vulva hygiene, diet makan yang tidak diperbolehkan saat keputihan, terapi obat yaitu dexamethasone dan B complek.

Berdasarkan dari asuhan yang diberikan ditemukan hambatan yaitu pasien tidak diberikan terapi ekstrak belladona saja, tetapi pasien juga diberikan konseling tentang menjaga perawatan personal hygiene terutama vulva hygiene, makanan yang tidak diperbolehkan saat keputihan dan makanan yang mengurangi keputihan, serta memberikanterapi dexamethasone yaitu untuk anti inflamasi dan anti alergi yang sangat kuat dan B complek untuk vitamin terhadap kekebalan tubuh.

\section{SIMPULAN}

Berdasarkan hasil analisa dan pembahasan yang telah diuraikan pada bab sebelumnya, dapat ditarik simpulan pasien dengan flour albus di BPM Eni Nogosari Boyolali, telah dilakukan secara komprehensif. Penanganan yang diberikan berupa ekstrak belladona dengan dosis $10 \mathrm{mg}$ jumlah 50 tablet diminum $2 \times 1$ /hari yaitu pagi dan sore, setelah diberikan selama empat minggu yaitu terapi ekstrak belladona pasien tidak mengalami keputihan lagi. Terapi ekstrak belladona dikatakan efektif di dalam penanganan flour albus pada akseptor KB IUD yang berhubungan dengan antagonis kompetitif dan asetilkolin muscarinic. Tetapi dalam pelaksanaan harus dikombinasikan dengan dexamethasone 
yaitu untuk anti inflamasi dan anti alergi, B complek sebagai vitamin terhadap kekebalan tubuh, dan memberikan konseling personal hygiene, makanan yang dapat mengurangi keputihan seperti yogurt, sayur-sayuran, daun sirih yang direbus dan makanan yang dapat mengeluarkan keputihan seperti makanan yang mengandung ragi, buah-buahan yang dikeringkan serta see food.

\section{SARAN}

1. Bagi pasien

Diharapkan dapat memperhatikan perawatan personal hygiene untuk mencegah terjadinya flour albus.

2. Bagi peneliti selanjutnya

Diharapkan ada penelitian selanjutnya yang mengembangkan variabel penelitian menjadi lebih luas.

3. Bagi profesi dan tenaga kesehatan

Diharapkan dapatmemberikan pengetahuan tentang efek samping dari KB IUD dengan memperkenalkan terapi ekstrak belladona dan pengetahuan perawatan personal hygiene untuk mencegah terjadinya flour albus.

4. Bagi pelayanan di BPM

Diharapkan lebih meningkatkan pemberian asuhan kebidanan melalui pendekatan manajemen kebidanan secara tepat dan profesional untuk meningkatkan kualitas pelayanan sehingga pasien merasa aman dan nyaman terutama dalam pelayanan asuhan kebidanan pada akseptor KB IUD.

\section{REFERENSI}

BKKBN, 2012. KB Diarahkan ke Metode Jangka Panjang. Didapat dari:

http://jabar.bkkbn.go.id/ViewBerita.aspk?BeritaID $=294$, diakses tanggal 28 Februari 2015/ pkl 15.00 WIB

Depkes, 2010. Keluarga Berencana dan Kesehatan Reproduksi. Didapat dari: http://www.factsforlifeglobal.org/resource s/Facts-for-Life-BookIndonesia, diakses tanggal 28 Februari 2015/ pkl 09.07 WIB

Hidayat, A. Aziz Alimul. 2006. Pengantar Dokumentasi Proses Keperawatan. Jakarta: EGC

Leveno, Williams. 2012. Obstetrics Edition Study Guide. Didapat dari: http://jurnal.una ir.ac.id/filler/5.Wayan\%20Sumawan, diakses tanggal 1Maret 2015/ pkl 16.00 WIB

Manuaba, Ida Ayu Chandranita dan Fajar Manuaba. 2008. Gawat-Darurat ObstetriGinekologi dan Obstetri-Ginekologi Sosial Untuk Profesi Bidan. Jakarta: EGC

Martin, Willson. 2012. MIMS-Official Drug Reference for Indonesian Medical Proffesion. Yogyakarta: Tamer Jakarta

Nugroho, S. 2010. Catatan Kuliah Ginekologi Obstetri (Obsgyn). Yogyakarta: Nuha Medika

Saifuddin, Abdul Bari. 2012. Buku Panduan Praktis Pelayanan Kontrasepsi. Jakarta: Yayasan Bina Pustaka Sarwono Prawirohardjo

SDKI, 2012. Badan Kependudukan dan Keluarga Berencana Nasional. Didapat dari: http://www.indosiar.com/ragam/fenomena keluargabahagia736444.html, diakses tanggal: 28 Februari 2015/ pkl 14.00 WIB 